\title{
Response of wheat cultivars to foliar potassium fertilization under irrigated saline environment
}

\author{
M. Kumar ${ }^{1}$, A. Sarangi ${ }^{2 *}$, D. K. Singh ${ }^{3}$, A.R. Rao $^{4}$, S. Sudhishri ${ }^{5}$ \\ ${ }^{1}$ Division of Agricultural Engineering, Pusa Campus, ICAR-IARI, New Delhi -110012, INDIA \\ ${ }^{2,3,5}$ Water Technology Centre, Pusa Campus, ICAR-IARI, New Delhi -110012, INDIA \\ ${ }^{4}$ Biometrics Division, ICAR-IASRI, New Delhi-110012, INDIA \\ *Corresponding author. E-mail: asarangi@iari.res.in
}

Received: July 30, 2015; Revised received: December 5, 2015; Accepted: March 16, 2016

\begin{abstract}
A field experiment with split-split plot design (SSPD) was conducted to study the response of two winter wheat (Triticumaestivum L.) cultivars (viz. salt tolerant cultivar KRL-1-4 and salt non-tolerant cultivar HD-2894) under saline irrigation regimes with and without foliar potassium fertilization on growth and grain yield of wheat during rabi 2011-12 and 2012-13. Potassium in the ratio of $\mathrm{K}^{+}: \mathrm{Na}^{+}(1: 10)$ was applied as foliar application during the heading stage of the crop. Results showed that the grain yield of KRL-1-4 and HD-2894 cultivars with foliar potassium fertilization at the heading stage increased by 6.5 to $22 \%$ and 3 to $15 \%$ during rabi $2011-2012$, respectively under different saline irrigation regimes as compared to the control. Moreover, the results of rabi 2012-13 showed an increase in grain yield ranging from 4.5 to $20 \%$ for KRL-1-4 as compared to the control. Statistical analysis of grain yield parameter showed that the foliar potassium application in both varieties resulted in significant yield difference at 0.05 probability level as compared to the non-foliar application. Overall, it was observed that the foliar potassium fertilization increased the grain yield of both wheat cultivars, while the salt tolerant cultivar performed better than the salt non-tolerant cultivar under irrigated saline regimes.
\end{abstract}

Keywords: Foliar potassium fertilization; Saline water; Salt-tolerant cultivar; Surface irrigation; Wheat yield

\section{INTRODUCTION}

Wheat (Triticum asestivum, L.) is one of the major cereal crops cultivated to meet the food demand of the burgeoning population. The total wheat production in India during the year 2012-13 was 93.5 million tonnes (Anonymous, 2014). Rapid increase in wheat consumption due to population growth is projected to outpace the domestic production. Besides this, the salinity of soil and ground water resource is posing a major problem for irrigated agriculture in many parts of the world. Excess amount of salt in the soil adversely affects the growth and development of plant. Nearly $20 \%$ of the world's cultivated area and about half of the world's irrigated lands are affected by salinity (Sattar et al., 2010). Out of 328.73 million hectares (mha) geographical area of India, about $120.40 \mathrm{mha}$ $(37 \%)$ is affected by various kind of land degradation (Anonymous, 2014).

Development of salt tolerant cultivars is widely recognized as an effective way to overcome the limitations of crop production in a salinized area (Munns and James, 2003). India is also facing problems of reduction in quantity of irrigation water coupled with poor water quality. One of the important reasons for decrease of crop yield is the degradation of irrigation water quality due to improper agricultural water man- agement practices and over exploitation of available water resources. Salt-affected irrigated land in the world and in India is about $20 \%$ and $17 \%$ of total irrigated land, respectively (Ghassemi et al., 1995). Moreover, $0.2-0.4 \%$ of the total arable land every year is going out of cultivation because of salinity and water logging problem (Jabeen and Ahmad, 2012). Therefore, it is imperative to develop appropriate package and practices of raising different crops and water management technologies for enhancing productivity from irrigated saline environment to feed the ever increasing population. Wheat cultivation under irrigated saline environment requires judicious application of different nutrients besides agricultural water management. The growth and yield of wheat under the irrigated conditions is affected by soil-water-plantatmospheric parameters of the region. Therefore, field experiments assist in generation of primary data to investigate the effect of these parameters on yield of wheat crop. Khan et al. (2006) conducted experiments to evaluate the response of wheat to foliar application of $\mathrm{N}$ and $\mathrm{K}$ under rainfed conditions and observed that both $\mathrm{KNO}_{3}$ and $\mathrm{KCl}$ used as foliar spray were equally effective in increasing wheat yield. Mesbah (2009) reported that foliar spraying of potassium in wheat has increased the grain yield, which could be attributable to the increased leaf area index and number of tillers. 
Sawan et al. (2009) reported that the foliar application of potassium fertilizer increased the seed yield of Egyptian cotton by 10.02 to $16.26 \%$. Hussein et al. (2010) conducted experiment in green house on sorghum and reported that application of $\mathrm{P}$ and $\mathrm{K}$ as foliar spray under $5000 \mathrm{ppm}$ salinity could not mitigate the effect of salt stress on crop yield. Asgari et al. (2012) observed that different wheat cultivars exhibited varied response on the plant growth and grain yield under different $\mathrm{K}^{+}: \mathrm{Na}^{+}$ratio. Khan and Aziz (2013) observed that foliar application@ $300 \mathrm{mgL}^{-1}$ of $\mathrm{K}$ was more effective in enhancing grain yield of wheat under saline environment. Sharma and Chaudhari (2012) reported that farmers' in the Northern region of India apply high doses of nitrogenous fertilizers and avoid application of recommended dose of potassium fertilizer, which not only causes imbalance in the nutrition and also affects the soil health. Therefore, it was recommended to conduct location specific research to study the effect of potassium application under irrigated saline environment. Keeping in view of the above findings and suggestions on enhancing productivity from irrigated saline environment, an experiment was undertaken to study the effect of foliar potassium application on two wheat cultivars (i.e. one salttolerant cultivar KRL-1-4 and the other salt nontolerant cultivar HD-2894) irrigated under varying saline irrigation regimes in the semi-arid region of New Delhi, India.

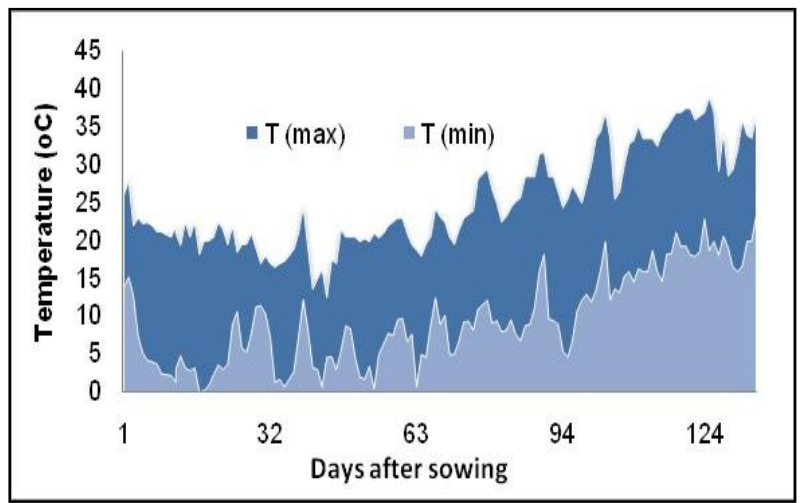

\section{MATERIALS AND METHODS}

Site description: The experimental field is located in the research farm of Water Technology Centre, Indian Agricultural Research Institute (IARI), New Delhi. The experiment was conducted during rabi season of 2011-12 and 2012-13. IARI farm is situated between $77^{\circ} 09^{\prime} 36^{\prime}$ ' E longitude and $28^{\circ} 37^{\prime} 55^{\prime \prime} \mathrm{N}$ latitude at an average elevation of $230 \mathrm{~m}$ above MSL (mean sea level). The experimental farm was equipped with surface irrigation facility having an overhead tank to store and prepare artificial saline water of different salinity levels for subsequent irrigation to different experimental plots. Climate data during the experiment period was acquired from the observatory located adjacent to the experiment site. Rainfall depth and temperature during the crop growing period for rabi 2011-12 and 2012-13 is presented in Figs. 1 and 2 , respectively.

Field layout and treatment levels: Field experiment was laid out in split-split plot design with four main plots and three replications (Fig. 3). Main plots were irrigated with four different salinity levels [i.e. $\mathrm{S}_{1}(1.7$ $\mathrm{dS} / \mathrm{m}$, ground water salinity): $\mathrm{S}_{2}(4 \mathrm{dS} / \mathrm{m}): \mathrm{S}_{3}(8 \mathrm{dS} / \mathrm{m})$ and $\left.\mathrm{S}_{4}(12 \mathrm{dS} / \mathrm{m})\right]$. Each sub-plot consisted of foliar potassium $\left(\mathrm{F}_{1}\right)$ and non-foliar potassium $\left(\mathrm{F}_{0}\right)$ treatments on both wheat cultivars. Further, each sub-plot was again divided into two sub-sub-plots to accommodate two different wheat cultivars with $\mathrm{V}_{1}$ as salt toler-

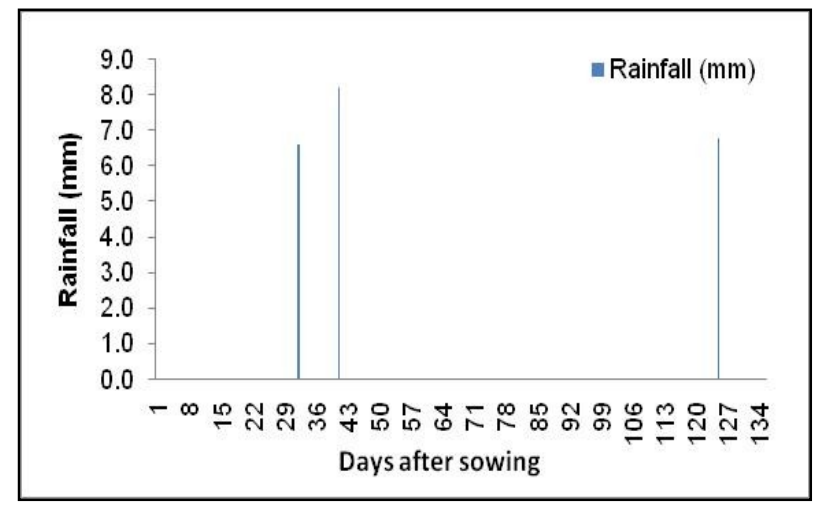

Fig. 1. Temperature and rainfall during wheat growth period (rabi 2011-2012).
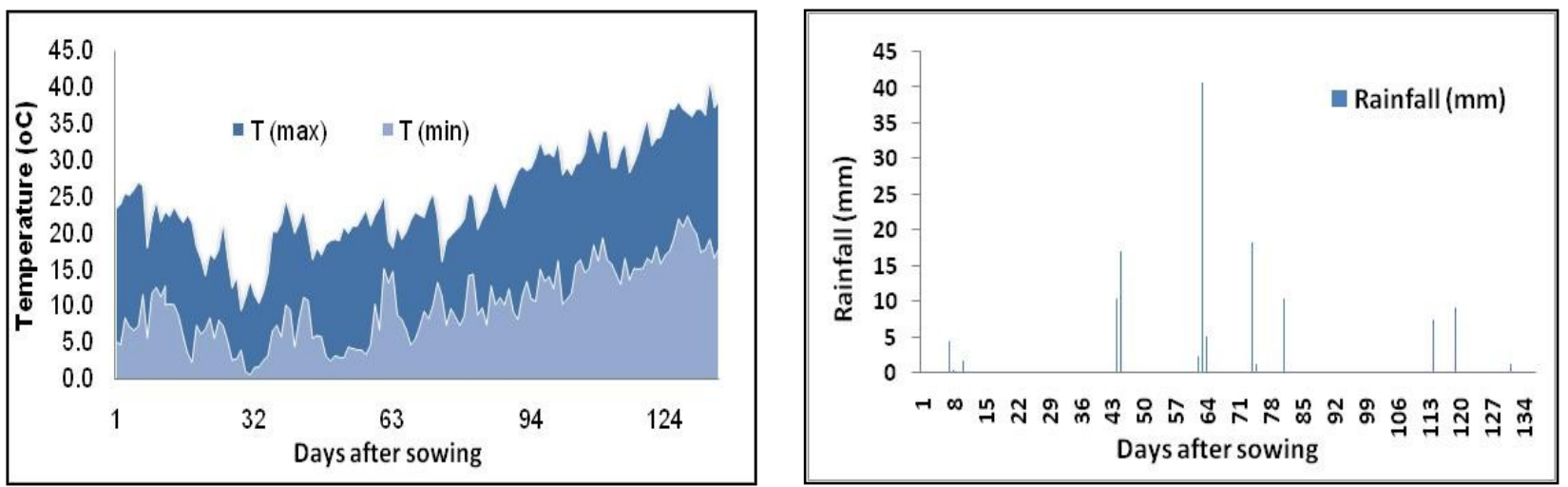

Fig. 2. Temperature and rainfall during wheat growth period (rabi 2012-2013). 


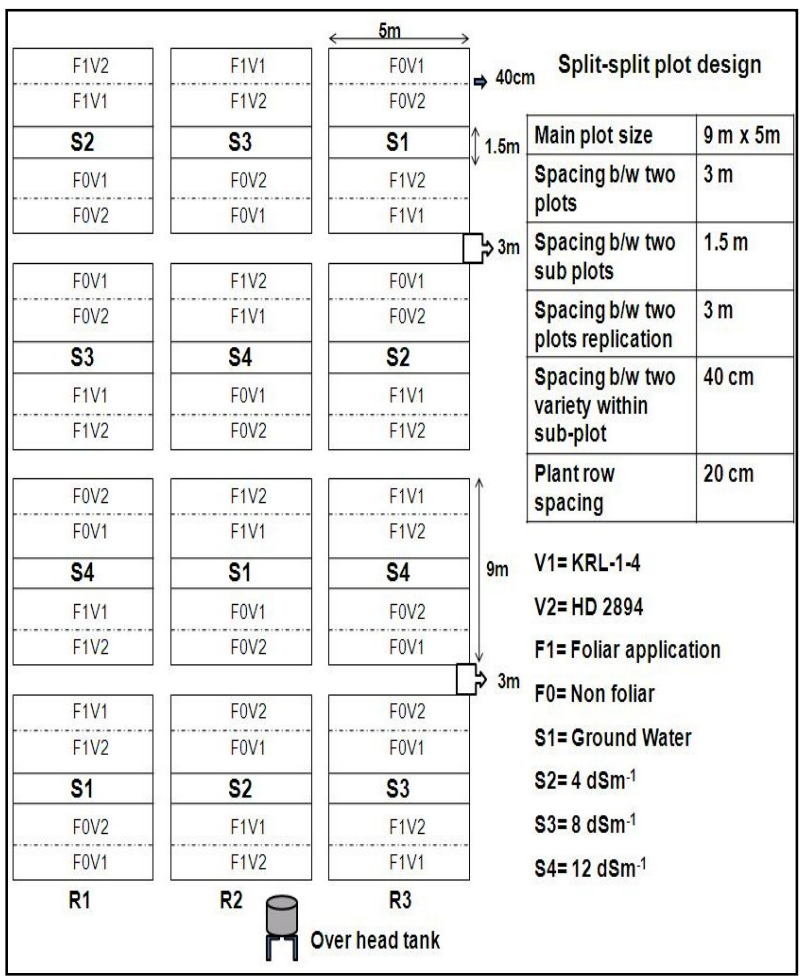

Fig.3. Layout of the experimental field [Split-split Plot Design (SSPD)].

ant (KRL-1-4) and $\mathrm{V}_{2}$ as salt non-tolerant (HD 2894) wheat cultivar. The size of the main plot was $9 \mathrm{~m} \times 5 \mathrm{~m}$ and the spacing between two main plots was $3 \mathrm{~m}$. The spacing between two sub-plots was $1.5 \mathrm{~m}$ within the main plot. The wheat cultivars were sown with row to row spacing of $20 \mathrm{~cm}$ on December 8, 2011 and December 5, 2012 and harvested on April 20, 2012 and April 19, 2013 during rabi 2011-12 and 2012-13, respectively.

Different levels of saline irrigation water was prepared artificially by mixing three different salts viz. $\mathrm{NaCl}$, $\mathrm{MgSO}_{4}, \mathrm{CaCl}_{2}$ in the ratio 2.5: 1.5: 1, respectively with the ground water available for irrigation in the farm. The saline water was prepared in the overhead tank and surface irrigation was applied through portable pipe line system laid in the entire experimental area. Potassium sulphate was used for foliar application in the experiment. Foliar potassium in the ratio of $\mathrm{K}^{+}$: $\mathrm{Na}^{+}$(1: 10) was applied during the heading stage of the crop for three consecutive days (i.e. $18^{\text {th }}$ to $20^{\text {th }}$ February 2012 and $15^{\text {th }}$ to $17^{\text {th }}$ February 2013 during rabi 2011-12 and rabi 2012-13, respectively). The quantity of foliar potassium fertilization applied was estimated based on $\mathrm{K}^{+}: \mathrm{Na}^{+}(1: 10)$ ratio and the quantity of $\mathrm{Na}^{+}$supplied to different plots based on different levels of irrigation water salinity and its quantity (Zheng et al., 2010).

Data acquisition from the experiment: Physical and chemical properties of soil were analyzed by collecting soil samples before and after conduction of experiment each year. Initial soil salinity, potassium content, soil moisture content and salinity indifferent root zone depths (i.e. 0-15, 15-30, 30-45 and 45-90 cm) of wheat were estimated periodically during the experiment. Besides this, the plant height, LAI (leaf area index) acquired using plant canopy analyzer equipment, maximum rooting depth at different growth stages of the crop and grain and biomass yield after crop harvest was recorded for both years of experiment.

Scheduling of irrigation in the experiment: Irrigation water was applied based on the concept of soil moisture deficit through application of measured quantity of irrigation water needed to bring the soil moisture content to the field capacity from the present moisture level and the root zone depth of crop on the date of irrigation. For this purpose, the moisture content of soil profile upto the root zone depth was measured periodically. The date of irrigation was decided based on the available moisture content of the soil root zone when it dropped to $50 \%$ of the total available water (TAW). Quantity of irrigation water on volume basis applied to each treatment was estimated using the equation given below,

$$
V(l)=P A \times \frac{F C-M C_{b i}}{100} \times B D \times R Z D \times 1000
$$

Where,

$\mathrm{V}(l)$ : volume of water in litre;

FC: field capacity (\%);

$\mathrm{MC}_{\mathrm{bi}}$ : moisture content before irrigation (\%);

$\mathrm{BD}$ : bulk density (gm/cc);

RZD:root zone depth (m);

PA:plot area $\left(\mathrm{m}^{2}\right)$

Statistical Analysis: The data was analysed using procglm module of SAS version 9.3software. The null hypothesis of equality of main-plot treatment effects, sub-plot treatment effects and sub-sub-plot treatment effects were tested for its significance using $F$-ratio obtained from analysis of variance (ANOVA) estimation. The critical difference (CD) for estimated treatment contrasts were worked out using standard statistical procedures as outlined in Dean and Voss (2001). The difference between treatment means were compared with $C D$ value and the treatments with higher effect over others were identified.

\section{RESULTS AND DISCUSSION}

LAI of wheat cultivars under different treatments: Leaf Area Index (LAI) of wheat cultivars under varying salinity regimes and foliar and non-foliar fertilization levels at different crop growth stages were analyzed and presented in Fig. 4. It was observed from Fig. 4 that the maximum LAI value for salt tolerant (KRL-1-4) cultivar showed minimal variation (i.e. $3 \%$ to $16 \%$ ) from $\mathrm{S}_{2}(4 \mathrm{dS} / \mathrm{m})$ to $\mathrm{S}_{4}(12 \mathrm{dS} / \mathrm{m})$ salinity regimes as compared to the control $(1.7 \mathrm{dS} / \mathrm{m})$ under non -foliar treatment. Whereas, the maximum LAI of salt non-tolerant cultivar (HD-2894) showed significant variation ranging from $3.4 \%$ to $33 \%$ from $\mathrm{S}_{2}(4 \mathrm{dS} / \mathrm{m})$ to $\mathrm{S}_{4}(12 \mathrm{dS} / \mathrm{m})$ salinity level under non-foliar treatment. Moreover, the maximum LAI of KRL-1-4 culti- 
var treated with foliar potassium was found to be varying from $5.6 \%$ to $16 \%$ for $\mathrm{S}_{2}(4 \mathrm{dS} / \mathrm{m})$ to $\mathrm{S}_{4}(12 \mathrm{dS} / \mathrm{m})$ salinity regimes as compared to the control. Whereas, the maximum LAI of HD 2894 varied from 6\% to $23 \%$ for $\mathrm{S}_{2}$ to $\mathrm{S}_{4}$ salinity regimes as compared to the control. However, it was also noticed that the maximum LAI of HD-2894 was less than the maximum LAI of KRL-1-4 at higher salinity levels of 8 and $12 \mathrm{dS} / \mathrm{m}$. This may be attributed to the effect of salinity induced stress in the salt tolerant cultivar as compared to the salt nontolerant cultivar at these higher salinity levels. It was also observed that the LAI value of HD-2894 cultivar was considerably less at 8 and $12 \mathrm{dS} / \mathrm{m}$ salinity levels as compared to lower salinity levels of 1.7 and $4 \mathrm{dS} / \mathrm{m}$. Whereas, the LAI of the same cultivar when treated with foliar potassium fertilization exhibited an increase in LAI with salinity levels of 8 and $12 \mathrm{dS} / \mathrm{m}$. Therefore, it was revealed that the application of foliar potassium fertilizer might have minimized the salinity stress and resulted in higher LAI leading to higher grain and biomass yield at higher salinity levels as compared to the non-foliar treatment. Similar results were also reported by Zheng et al., 2010 in which the foliar application of $\mathrm{K}^{+}$resulted in higher LAI of both salt-tolerant and salt-non tolerant wheat cultivars.

Grain yield of wheat cultivars under non-foliar and foliar potassium application: It was observed that the KRL-1-4 cultivar treated with foliar potassium doses resulted in the grain yield of $4.81,4.62,4.45$ and 3.50 $\mathrm{t} /$ ha for the salinity levels of $1.7,4,8,12 \mathrm{dS} / \mathrm{m}$, respectively (Table 1). Grain yield of KRL-1-4 without foliar potassium fertilization was found to be 4.52, 4.12, 3.65 and 3.15 t/ha under $S_{1}, S_{2}, S_{3}$ and $S_{4}$ salinity levels, respectively. Grain yield of HD-2894 cultivar for rabi
2011-12 treated with foliar potassium was found to be 5.1, 4.58, 3.53 and $2.34 \mathrm{t} /$ ha at $\mathrm{S}_{1}, \mathrm{~S}_{2}, \mathrm{~S}_{3}$ and $\mathrm{S}_{4}$ salinity levels, respectively. The yield of same cultivar without foliar application of potassium fertilizer was observed to be $4.86,4.25,3.06$ and $2.27 \mathrm{t} /$ ha for $\mathrm{S}_{1}, \mathrm{~S}_{2}, \mathrm{~S}_{3}$ and $\mathrm{S}_{4}$ salinity levels, respectively. Overall, the KRL-1-4 cultivar under foliar potassium treatment resulted in increase of grain yield by 6.5 to $22 \%$ as compared to the non-foliar treatments with irrigation water salinity ranging from 1.7 to $12 \mathrm{dS} / \mathrm{m}$. The increase in yield of wheat with foliar potassium fertilization over the nonfoliar application for the HD-2894 cultivar was found to vary from 3 to $15 \%$ for irrigation water salinity up to $12 \mathrm{dS} / \mathrm{m}$. Moreover, under the same treatment combinations, the grain yield of both cultivars under irrigated saline regimes for rabi 2012-13 are presented in Table 2. It was observed from Table 2 that the grain yield of KRL-1-4 treated with foliar potassium fertilization was found to be 5.08, 4.93, 4.41 and $3.11 \mathrm{t} / \mathrm{ha}$ at $1.7,4,8,12 \mathrm{dS} / \mathrm{m}$, respectively. The grain yield of the same cultivar without foliar potassium application was found to be 4.86, 4.42, 3.68 and $2.85 \mathrm{t} / \mathrm{ha}$ at $\mathrm{S}_{1}, \mathrm{~S}_{2}, \mathrm{~S}_{3}$ and $\mathrm{S}_{4}$ salinity levels, respectively. The grain yield of HD-2894 treated with foliar potassium was 5.22, 4.91, 3.55 and $2.08 \mathrm{t} /$ ha at $\mathrm{S}_{1}, \mathrm{~S}_{2}, \mathrm{~S}_{3}$ and $\mathrm{S}_{4}$ salinity levels, respectively. The grain yield of the same cultivar without foliar spray was observed to be $5.11,4.51,3.12$ and 1.94 at $\mathrm{S}_{1}, \mathrm{~S}_{2}, \mathrm{~S}_{3}$ and $\mathrm{S}_{4}$ salinity levels, respectively. Nonetheless, the foliar potassium fertilization resulted in enhancing the grain yield of KRL-1-4 cultivar by $4.5 \%$ to $20 \%$ as compared to the control under all salinity levels. Whereas, for the HD-2894 cultivar, the increased yield due to foliar potassium fertilization varied from 2 to $14 \%$ as compared to the non-foliar

Table 1. Grain yield of wheat cultivars with and without foliar potassium fertilization under irrigated saline regimes with three replication during rabi 2011-2012.

\begin{tabular}{|c|c|c|c|c|c|}
\hline Variety & Salinity & $\begin{array}{c}\text { Foliar } \\
\text { Yield }\left(\text { tha }^{-1}\right)\end{array}$ & Standard Error & $\frac{\text { Non-foliar }}{\text { Yield }\left(\text { tha }^{-1}\right)}$ & Standard Error \\
\hline \multirow{4}{*}{ KRL-1-4 } & $\mathrm{S}_{1}$ (control) & 4.81 & \pm 0.225 & 4.52 & \pm 0.342 \\
\hline & $\mathrm{S}_{2}\left(4 \mathrm{dSm}^{-1}\right)$ & 4.62 & \pm 0.161 & 4.12 & \pm 0.264 \\
\hline & $\mathrm{S}_{3}\left(8 \mathrm{dSm}^{-1}\right)$ & 4.45 & \pm 0.116 & 3.65 & \pm 0.174 \\
\hline & $\mathrm{S}_{4}\left(12 \mathrm{dSm}^{-1}\right)$ & 3.50 & \pm 0.203 & 3.15 & \pm 0.152 \\
\hline \multirow[t]{4}{*}{ HD 2894} & $\mathrm{~S}_{1}$ (control) & 5.10 & \pm 0.214 & 4.86 & \pm 0.125 \\
\hline & $\mathrm{S}_{2}\left(4 \mathrm{dSm}^{-1}\right)$ & 4.58 & \pm 0.129 & 4.25 & \pm 0.216 \\
\hline & $\mathrm{S}_{3}\left(8 \mathrm{dSm}^{-1}\right)$ & 3.53 & \pm 0.397 & 3.06 & \pm 0.204 \\
\hline & $\mathrm{S}_{4}\left(12 \mathrm{dSm}^{-1}\right)$ & 2.34 & \pm 0.187 & 2.27 & \pm 0.210 \\
\hline
\end{tabular}

Table 2. Grain yield of wheat cultivars with and without foliar potassium fertilization under irrigated saline regimes with three replication during rabi 2012-2013.

\begin{tabular}{|c|c|c|c|c|c|}
\hline Variety & Salinity & $\begin{array}{c}\text { Foliar } \\
\text { Yield }\left(\mathrm{t} \mathrm{ha}^{-1}\right)\end{array}$ & Standard Error & $\begin{array}{c}\text { Non-foliar } \\
\text { Yield }\left(\mathrm{t} \mathrm{ha}^{-1}\right)\end{array}$ & $\begin{array}{c}\text { Standard Er- } \\
\text { ror }\end{array}$ \\
\hline \multirow{4}{*}{ KRL-1-4 } & $\mathrm{S}_{1}$ (control) & 5.08 & \pm 0.138 & 4.86 & \pm 0.094 \\
\hline & $\mathrm{S}_{2}\left(4 \mathrm{dSm}^{-1}\right)$ & 4.93 & \pm 0.165 & 4.42 & \pm 0.072 \\
\hline & $\mathrm{S}_{3}\left(8 \mathrm{dSm}^{-1}\right)$ & 4.41 & \pm 0.097 & 3.68 & \pm 0.082 \\
\hline & $\mathrm{S}_{4}\left(12 \mathrm{dSm}^{-1}\right)$ & 3.11 & \pm 0.311 & 2.85 & \pm 0.255 \\
\hline \multirow{4}{*}{ HD 2894} & $\mathrm{~S}_{1}$ (control) & 5.22 & \pm 0.081 & 5.11 & \pm 0.146 \\
\hline & $\mathrm{S}_{2}\left(4 \mathrm{dSm}^{-1}\right)$ & 4.91 & \pm 0.134 & 4.51 & \pm 0.117 \\
\hline & $\mathrm{S}_{3}\left(8 \mathrm{dSm}^{-1}\right)$ & 3.55 & \pm 0.290 & 3.12 & \pm 0.335 \\
\hline & $\mathrm{S}_{4}\left(12 \mathrm{dSm}^{-1}\right)$ & 2.08 & \pm 0.223 & 1.94 & \pm 0.254 \\
\hline
\end{tabular}


Table 3. Combined ANOVA for both the years (rabi 2011-2012 and 2012-2013).

\begin{tabular}{|c|c|c|c|c|}
\hline Source & $d f$ & Mean Square & F-Ratio & $\operatorname{Pr}>\mathbf{F}$ \\
\hline Replication & 2 & 0.5525 & 1.5038 & \\
\hline Year & 1 & 0.0844 & 0.2297 & 0.6790 \\
\hline Error(a) & 2 & 0.3674 & & \\
\hline Salinity & 3 & 24.7121 & 256.0839 & $<0.0001$ \\
\hline Year*Salinity & 3 & 0.4776 & 4.9492 & 0.0183 \\
\hline Error(b) & 12 & 0.0965 & & \\
\hline Foliar & 1 & 3.2233 & 38.1004 & $<0.0001$ \\
\hline Year*Foliar & 1 & 0.0063 & 0.0744 & 0.7885 \\
\hline Salinity*Foliar & 3 & 0.2229 & 2.6347 & 0.0853 \\
\hline Year*Salinity*Foliar & 3 & 0.0062 & 0.0732 & 0.9735 \\
\hline Error(c) & 16 & 0.0846 & & \\
\hline Variety & 1 & 3.0534 & 24.7439 & $<0.0001$ \\
\hline Year*Variety & 1 & 0.0005 & 0.0040 & 0.9455 \\
\hline Salinity*Variety & 3 & 2.1680 & 17.5688 & $<0.0001$ \\
\hline Year*Salinity*Variety & 3 & 0.0094 & 0.0761 & 0.9723 \\
\hline Foliar*Variety & 1 & 0.2013 & 1.6312 & 0.2106 \\
\hline Year*Foliar*Variety & 1 & 0.0039 & 0.0316 & 0.8584 \\
\hline Salinity*Foliar*Variety & 3 & 0.0151 & 0.1223 & 0.9461 \\
\hline Year*Salinity*Foliar*Variety & 3 & 0.0028 & 0.0226 & 0.9952 \\
\hline Error(d) & 32 & 0.1234 & & \\
\hline Total & 95 & & & \\
\hline
\end{tabular}

Table 4. Crop season wise ANOVA for grain yield of wheat under Split-split plot design.

\begin{tabular}{lccccccc}
\hline \multirow{2}{*}{ Source } & \multirow{2}{*}{$\boldsymbol{d f}$} & \multicolumn{3}{c}{ rabi 2011-2012 } & \multicolumn{3}{c}{ rabi 2012-2013 } \\
\cline { 3 - 8 } & & Mean Square & F-Ratio & Pr $>$ F & Mean Square & F-Ratio & Pr $>$ F \\
\hline Replication & 2 & 0.7814 & 15.1306 & & 0.1384 & 0.9787 & \\
Salinity & 3 & 9.2738 & 179.5692 & $<.0001$ & 15.9144 & 112.5282 & $<.0001$ \\
Error (a) & 6 & 0.0516 & & & 0.1414 & & \\
Foliar & 1 & 1.7580 & 20.4606 & 0.0019 & 1.4713 & 17.6620 & 0.0030 \\
Salinity*Foliar & 3 & 0.1065 & 1.2397 & 0.3575 & 0.1226 & 1.4722 & 0.2936 \\
Error (b) & 8 & 0.0859 & & & 0.0833 & & \\
Variety & 1 & 1.4847 & 11.3758 & 0.0039 & 1.5685 & 13.4833 & 0.0021 \\
Salinity*Variety & 3 & 1.2106 & 9.2755 & 0.0009 & 0.9672 & 8.3148 & 0.0015 \\
Foliar*Variety & 1 & 0.1310 & 1.0040 & 0.3313 & 0.0742 & 0.6382 & 0.4361 \\
Salinity*Foliar*Variety & 3 & 0.0111 & 0.0848 & 0.9674 & 0.0069 & 0.0592 & 0.9804 \\
Error (c) & 16 & 0.1305 & & & 0.1163 & & \\
Total & 47 & & & & & & \\
\hline
\end{tabular}

treatment. The trend of increase in grain yield for rabi 2012-13 was in line with the results of rabi 2011-12. Overall, it was observed that the grain yield of both cultivars showed increase in the grain yield due to foliar potassium application. However, the effect of salinity on yield reduction of salt non-tolerant cultivar was more pronounced at salinity levels of $4 \mathrm{dS} / \mathrm{m}$ and above. Also, the percent increase of grain yield due to foliar potassium at salinity level of 4 and $8 \mathrm{dS} / \mathrm{m}$ was observed to be higher than that at salinity regimes of 1.7 and $12 \mathrm{dS} / \mathrm{m}$. Moreover, the salt non-tolerant wheat cultivar (HD-2894) exhibited higher grain yield than the salt tolerant wheat cultivar (KRL-1-4) at lower salinity level of $1.7 \mathrm{dS} / \mathrm{m}$. However, at higher salinity levels (i.e. 8 to $12 \mathrm{dS} / \mathrm{m}$ ), the KRL-1-4 cultivar produced more grain yield than the HD-2894 cultivar under both foliar and non-foliar potassium fertilizer application. These findings are in line with the results reported by Khan et al. (2006) , Mesbah (2009), Zheng et al., 2010, Ashraf et al. (2013), Khan and Aziz (2013) in which the foliar potassium fertilization in pot and field experiments at specific crop growth stages resulted in higher grain yield of wheat.

Statistical analysis of wheat yield under different treatment levels: Analysis of variance (ANOVA) under split-split plot design (SSPD) for the grain yield of wheat for both the years (i.e. rabi season of 2011-12 and 2012-13) considering year as an additional factor beside other main factors (viz., Salinity, foliar and cultivars) is presented in Table 3. Among the main effects, the effects of salinity, foliar application and cultivars on the grain yield of wheat were found to be significant at 0.01 probability level. Further, the interaction effects of year and salinity and salinity and variety on grain yield were found to be significant at $5 \%$ and $1 \%$ level of significance, respectively. However, the interaction effect of salinity and foliar application was found to be significant at $10 \%$ level of significance as shown in the Table 3 . Since the year and salinity interaction effect was found significant, a sepa- 
Table 5. Analysis of mean differences for rabi 2011-2012.

\begin{tabular}{|c|c|c|c|c|c|c|c|}
\hline \multicolumn{2}{|c|}{ Difference in salinity means } & \multicolumn{3}{|c|}{$\begin{array}{l}\text { Difference in variety means at the } \\
\text { same level of salinity }\end{array}$} & \multicolumn{3}{|c|}{$\begin{array}{l}\text { Difference in salinity means at the } \\
\text { same or different levels of variety }\end{array}$} \\
\hline S1 & A & \multirow{3}{*}{ S1 } & V1 & 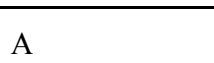 & \multirow{5}{*}{ V1 } & $\mathrm{S} 1$ & A \\
\hline S2 & $\mathrm{B}$ & & & & & & \\
\hline $\begin{array}{l}\text { S3 } \\
\text { S4 }\end{array}$ & $\begin{array}{l}\text { C } \\
D\end{array}$ & & V2 & A & & $\mathrm{S} 2$ & A \\
\hline Difference & & \multirow[b]{2}{*}{ S2 } & V1 & A & & S3 & A \\
\hline $\begin{array}{l}\text { Foliar } \\
\text { Non-foliar }\end{array}$ & $\begin{array}{l}\text { A } \\
\mathrm{B}\end{array}$ & & V2 & A & & S4 & B \\
\hline \multicolumn{2}{|c|}{ Difference in Variety means } & $\mathrm{S} 3$ & $\begin{array}{l}\text { V1 } \\
\text { V2 }\end{array}$ & $\begin{array}{l}\mathrm{A} \\
\mathrm{B}\end{array}$ & \multirow{2}{*}{$\mathrm{V} 2$} & $\begin{array}{l}\mathrm{S} 1 \\
\mathrm{~S} 2\end{array}$ & $\begin{array}{l}\mathrm{A} \\
\mathrm{B}\end{array}$ \\
\hline $\begin{array}{l}\text { V1 } \\
\text { V2 }\end{array}$ & $\begin{array}{l}\text { A } \\
\text { B }\end{array}$ & S4 & $\begin{array}{l}\text { V1 } \\
\text { V2 }\end{array}$ & $\begin{array}{l}\mathrm{A} \\
\mathrm{B}\end{array}$ & & $\begin{array}{l}\text { S3 } \\
\text { S4 }\end{array}$ & $\begin{array}{l}\mathrm{C} \\
\mathrm{D}\end{array}$ \\
\hline
\end{tabular}

Same alphabet indicate no significant difference between treatment/interaction effects

Table 6. Analysis of mean differences for rabi 2012-2013.

\begin{tabular}{|c|c|c|c|c|c|c|c|}
\hline \multicolumn{2}{|c|}{ Difference in salinity means } & \multicolumn{3}{|c|}{$\begin{array}{l}\text { Difference in variety means at the } \\
\text { same level of salinity }\end{array}$} & \multicolumn{3}{|c|}{$\begin{array}{l}\text { Difference in salinity means at the same or } \\
\text { different levels of variety }\end{array}$} \\
\hline S1 & A & \multirow{3}{*}{ S1 } & V1 & A & \multirow{5}{*}{ V1 } & S1 & A \\
\hline $\begin{array}{l}\mathrm{S} 2 \\
\mathrm{~S} 3\end{array}$ & $\begin{array}{l}\mathrm{B} \\
\mathrm{C}\end{array}$ & & & & & & \\
\hline S4 & $\mathrm{D}$ & & $\mathrm{V} 2$ & A & & S2 & A \\
\hline Difference & ans & \multirow[b]{2}{*}{ S2 } & V1 & A & & S3 & B \\
\hline $\begin{array}{l}\text { Foliar } \\
\text { Non-foliar }\end{array}$ & $\begin{array}{l}\text { A } \\
\text { B }\end{array}$ & & V2 & A & & S4 & $\mathrm{C}$ \\
\hline Difference & heans & S3 & $\begin{array}{l}\text { V1 } \\
\text { V2 }\end{array}$ & $\begin{array}{l}\mathrm{A} \\
\mathrm{B}\end{array}$ & \multirow{3}{*}{ V2 } & S1 & $\mathrm{A}$ \\
\hline V1 & A & \multirow{2}{*}{ S4 } & V1 & A & & $\mathrm{S} 3$ & $\begin{array}{l}\mathrm{A} \\
\mathrm{C}\end{array}$ \\
\hline V2 & B & & V2 & B & & S4 & B \\
\hline
\end{tabular}

Same alphabet indicate no significant difference between treatment/interaction effects

rate year-wise analysis of data was also undertaken and the difference in mean grain yield of different treatment and their interactions were analyzed seasonally. ANOVA of the grain yield under the split-split plot design for both the seasons with mean sum of square, F-ratio and $p$-value are presented in Table 4 . The main effects of salinity, foliar application, variety and interaction effect of salinity and variety were found to be significant at 0.01 probability level for both seasons. Further, the main effects and interaction effects which were found significant at 0.01 probability level were analyzed to determine the significant difference in treatment means and their interactions based on the CD (critical difference) values. Analysis of significant difference between means of treatment effects and their interactions for the rabi season 2011-2012 is presented in Table 5. The differences in salinity means at different levels viz. $1.7 \mathrm{dS} / \mathrm{m}, 4 \mathrm{dS} / \mathrm{m}, 8 \mathrm{dS} / \mathrm{m}, 12 \mathrm{dS} / \mathrm{m}$, respectively were found to be significant at 0.01 probability level. It was found that keeping other factors constant, all four levels of salinity have significantly decreased the grain yield of both wheat cultivars. Foliar and non-foliar potassium treatment means were found to be significantly different from each other. It was observed that there was significant effect of foliar potassium application on the grain yield of both wheat cultivars.
It was observed that both wheat cultivars have resulted in varying grain yields under different regime of saline irrigation and the foliar potassium treatments. The salinity and variety interaction effects were also studied and presented in Table 5. The difference in variety means at the same level of salinity for the year rabi 2011-2012 was analyzed. The difference in variety means at $S_{1}$ and $S_{2}$ levels of salinity did not exhibit significant difference. Whereas, the difference in variety means was found to be significant at $\mathrm{S}_{3}$ and $\mathrm{S}_{4} \mathrm{Sa}-$ linity regimes. The difference in salinity means at the same or different cultivar levels for rabi 2011-2012 was also analyzed and shown in Table 5. The differences among the means of salinity levels $\mathrm{S}_{1}, \mathrm{~S}_{2}$ and $\mathrm{S}_{3}$ for variety $\mathrm{V}_{1}$ did not exhibit significant difference but

Table 7. Harvest index of wheat cultivars at different salinity level (rabi2012-2013).

\begin{tabular}{lccc}
\hline \multirow{2}{*}{ Variety } & \multicolumn{3}{c}{ Harvest Index (\%) } \\
\cline { 2 - 4 } & Salinity & Non-foliar & Foliar \\
\hline \multirow{4}{*}{ V $_{1}$ (KRL-1-4) } & S1 & 41.9 & 42.5 \\
& S2 & 40.4 & 42.3 \\
& S3 & 38.4 & 40.3 \\
& S4 & 30.6 & 31.7 \\
V $_{2}$ (HD 2894) & S1 & 42.3 & 43.7 \\
& S2 & 41.2 & 42.7 \\
& S3 & 36.6 & 37.6 \\
& S4 & 26.4 & 29.4 \\
\hline
\end{tabular}



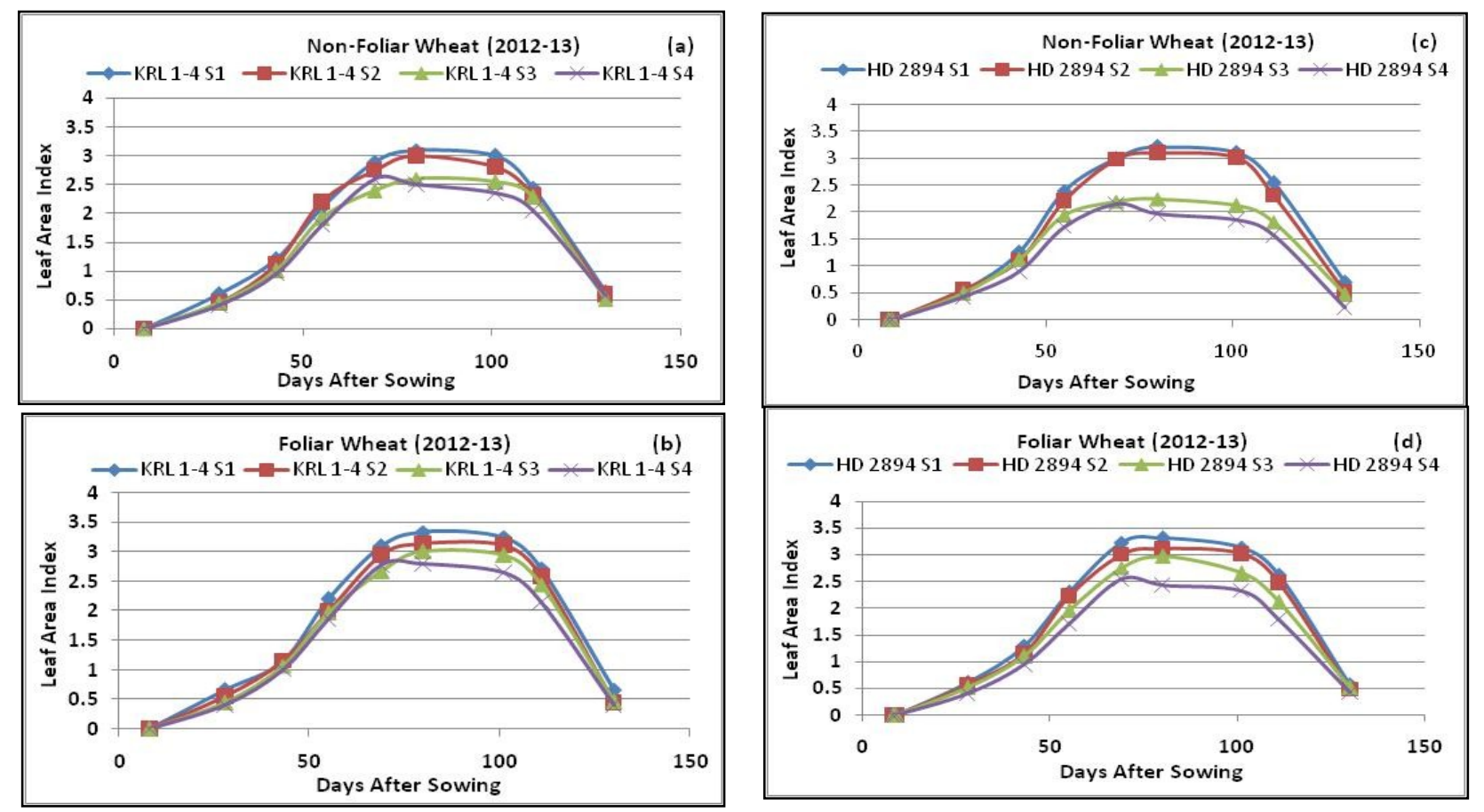

Fig. 4. Leaf area index of wheat cultivars with and without foliar potassium fertilization at different crop growth stages.

mean differences between $\mathrm{S}_{1}, \mathrm{~S}_{2}$ and $\mathrm{S}_{3}$ with respect to $\mathrm{S}_{4}$ was significantly different. However, for wheat cultivar $\mathrm{V}_{2}$, the differences in mean grain yield under all four salinity regimes (i.e. $\mathrm{S}_{1}, \mathrm{~S}_{2}, \mathrm{~S}_{3}$ and $\mathrm{S}_{4}$ ) levels were found to be significant at $1 \%$ level of significance (Table 5)

Moreover, similar analysis for the second year (i.e. rabi 2012-2013) data was also undertaken to evaluate the significant differences in means of main effects and interaction effects. Results of statistical analysis are presented in Table 6. Analysis of main factor and interaction effects pertaining to second year data (i.e. rabi 2012-13) were found to be in line with that of the first year data (i.e. rabi 2011-12) with an exception that there existed a significant difference between the means of salinity levels $\left(\mathrm{S}_{1}, \mathrm{~S}_{2}\right)$ as compared to salinity levels $\left(S_{3}, S_{4}\right)$ for varieties $V_{1}$ and $V_{2}$ (Table 6).

Harvest index (HI) of wheat cultivars under different treatment levels: Harvest index (HI) of wheat cultivars were found to decrease with increase in the irrigation water salinity level from $\mathrm{S}_{1}(1.7 \mathrm{dS} / \mathrm{m})$ to $\mathrm{S}_{4}$ $(12 \mathrm{dS} / \mathrm{m})$ under both foliar and non-foliar treatments. Analysis of data for rabi 2012-2013 showed that the harvest index of KRL-1-4 cultivar treated with foliar potassium fertilization varied from 42.5 to $31.7 \%$ for salinity levels ranging from $\mathrm{S}_{1}$ to $\mathrm{S}_{4}$. The harvest index of the same cultivar without foliar potassium application varied from 41.9 to $30.6 \%$ for saline irrigation water regimes of $\mathrm{S}_{1}$ to $\mathrm{S}_{4}$. The HI of salt non-tolerant cultivar HD-2894 treated with foliar potassium fertilization varied from 43.7 to $29.4 \%$ at salinity levels from $S_{1}$ to $S_{4}$, respectively. The HI of same cultivar without foliar potassium fertilization varied from 42.3 to $26.4 \%$ at salinity levels from $\mathrm{S}_{1}$ to $\mathrm{S}_{4}$ (Table 7 ).
Overall, it was estimated that the harvest index due to foliar potassium fertilization over non-foliar was found to increase by $0.6 \%, 1.9 \%, 1.9 \%$, and $1.1 \%$ for salt tolerant wheat cultivar KRL-1-4 at $\mathrm{S}_{1}, \mathrm{~S}_{2}, \mathrm{~S}_{3}$ and $\mathrm{S}_{4}$ salinity levels, respectively. Whereas, for salt nontolerant wheat cultivar HD 2894 the increase of HI due to foliar potassium fertilization was $1.4 \%, 1.5 \%, 1 \%$ and $3 \%$ at $S_{1}, S_{2}, S_{3}$ and $S_{4}$ salinity levels, respectively. Overall, it was observed that the foliar potassium application resulted in increase of HI resulting in better grain yield of both wheat cultivars under irrigated saline regimes.

\section{Conclusion}

Crop growth and yield is significantly affected under the irrigated saline environment. Experimental results in this study showed that the yield of salt tolerant and salt non-tolerant wheat cultivars were affected at higher salinity levels. Moreover, in an effort to enhance productivity from the irrigated saline environment, the present study on use of foliar potassium fertilization technology at the heading stage of the crop showed that the yield of both salt tolerant and salt nontolerant wheat cultivars can be increased upto $22 \%$ and $15 \%$, respectively under irrigation water salinity levels ranging from 4 to $12 \mathrm{dS} / \mathrm{m}$. Statistical analysis showed that the foliar potassium application resulted in significant yield difference of both varieties (i.e. KRL-1-4 and HD 2894) as compared to non-foliar application. It can be recommended to take up salt tolerant wheat cultivars besides the foliar potassium fertilization at heading stage of crop to enhance the grain yield in the regions affected by salinity problems. However, such study need to be undertaken in farmers field having 
saline ground water and saline soil to ascertain the results of foliar potassium fertilization in enhancing the grain yield of wheat as reported in this study.

\section{ACKNOWLEDGMENTS}

The authors wish to acknowledge the National Agricultural Innovation Project (NAIP) funding agency of Indian Council of Agricultural Research (ICAR) for providing the financial assistance under NAIP:70-22 project for undertaking the experiment at Water Technology Centre, Indian Agricultural Research Institute (IARI), New Delhi, India.

\section{REFERENCES}

Anonymous (2014). Annual Report 2014, Department of Agriculture and Cooperation, Ministry of Agriculture, Government of India, Krishi Bhawan, ICAR, New Delhi, India.

Asgari, H. R., Cornelis, W. and Van, D. P. (2012). Salt stress effect on wheat (Triticumaestivum L.) growth and leaf ion concentrations. Inter. J. of Plant Prod., 6 (2): 195208.

Ashraf, M. Y., Rafique, N., Ashraf, M., Azhar, N. and Marchand,M. (2013). Effect of supplemental potassium $(\mathrm{K}+)$ on growth, physiological andbiochemical attributes of wheat grown under saline conditions. J. Plant Nutr., 36: 443-458.

Dean, A. M. and Voss, D. (2001). Design and Analysis of Experiments, Springer, New York.

Ghassemi, F., Jakeman, A.J., Nix, H.A. (1995). Salinisation of land and water resources: Human causes, extent, management and case studied. UNSW Press, Sydney, Australia, and CAB International, Wallingford, UK.

Hussein, M., Abdel-Kader, A., Kady, K., Youssef, R. and Alva, A. (2010). Sorghum response to foliar application of phosphorus and potassium with saline water irrigation. J. of Crop Improv., 24: 324-336.
Jabeen, N. and Ahmad, R. (2012). Improving tolerance of sunflower and safflower during growth stages to salinity through foliar spray of nutrient solutions. Pak. J. Bot. 44(2): 563-572.

Khan, M.Z., Muhammad, S., Naeem, M.A., Akhtar, E. and Khalid, M. (2006). Response of some wheat (Triticumaestivum L.) Varieties to foliar application of N \& K under rainfed conditions. Pak. J. of Bot., 38(4): 1027-1034.

Khan, A. and Aziz, M.(2013). Influence of foliar application of potassium on wheat (triticumaestivum L.) under saline conditions. Sci. Tech. and Dev., 32 (4): 285-289.

Mesbah, E.A. E. (2009). Effect of irrigation regimes and foliar spraying of potassium on yield, yield component and water use efficiency of wheat (Triticumaestivum $L$.) in sandy soils. World J.of Agril. Sci., 5(6): 662-669.

Munns, R. and James, R.A. (2003). Screening methods for salt tolerance: A case study with tetraploid wheat. Plant Soil, 253: 239-250.

Sattar, S., Hussnain, T. and Javaid, A. (2010). Effect of $\mathrm{NaCl}$ salinity on cotton (GossypiumArboreum L.) grown on MS medium and in hydroponic cultures. The J.of Animal and Plant Sci., 20(2): 87-89

Sawan, Z.M., Fahmy, A.H. and Yousef, S.E. (2009). Direct and residual effects of nitrogen fertilization, foliar application of potassium and plant growth retardant on Egyptian cotton growth, seed yield, seed viability and seedling vigor. Acta Ecologica Sinica, 29:116-123.

Sharma, D.K. and Chaudhari, S.K. (2012). Agronomic research in salt affected soils of India: An overview. Indian J. of Agro., 57: 175-185.

Zheng, Y., Xu, X., Simmons, M., Zhang, C., Gao, F. and Li, Z. (2010). Responses of physiological parameters, grain yield, and grain quality to foliar application of potassium nitrate in two contrasting winter wheat cultivars under salinity stress. $J$ of Plant Nutri. Soil Sci., 173: 444-452. 